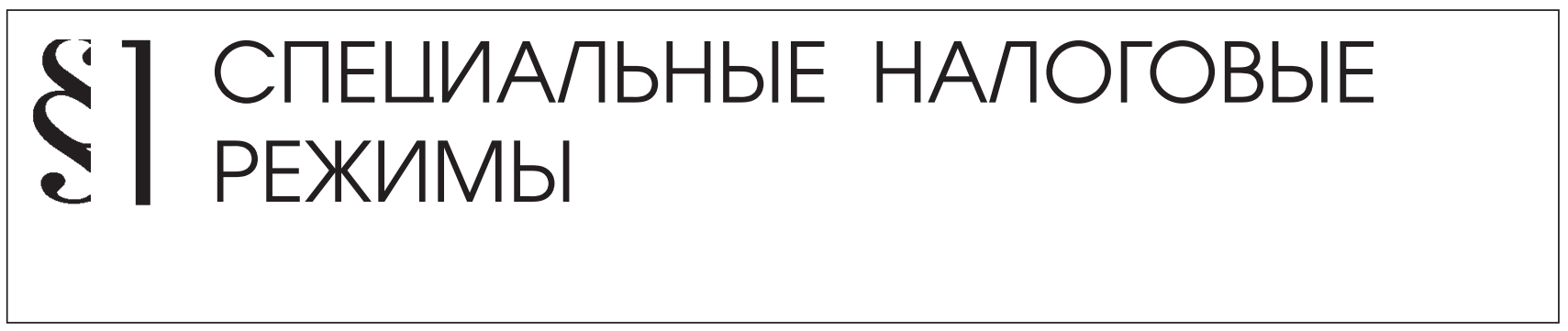

Оробинская И.В.

\title{
ИНТЕГРИРОВАННЫЕ ФОРМИРОВАНИЯ АПК, КАК СУБЪЕКТЫ НАЛОГОВЫХ ПРАВООТНОШЕНИЙ: ОСОБЕННОСТИ ПРИМЕНЕНИЯ ЛЬГОТ
}

Аннотация: Произошедшие в стране за последние годы политические, экономические и институциональные изменения объективно создали условия и дали импульс к возрождению, становлению и развитию интегрированных объединений в сельском хозяйстве. На сегодня интегрированные формирования занимают значимое место в производстве и реализации сельскохозяйственной продукции РФ. Вместе с тем в настоящее время существует ряд проблем, сдерживающих эффективное и устойчивое развитие исследуемых структур на селе, среди которых следует особо выделить проблему выбора оптимальной системы налогообложения. Существующая налоговая система недостаточно учитывает как специфику сельского хозяйства в целом, так и особенности функиионирования современных интегрированных структур в частности. Таким образом, в статье представлены особенности системы налогообложения сельскохозяйственных предприятий в России в разрезе интегрированных формирований АПК. Ключевые слова: Налоги и налогообложение, Интегированные формирования, АПК, Сельхозтоваропроизводители, Налоговая ситема, ЕСХН, НДС, ВТО, Таможенный тариф, Таможенная пошлина

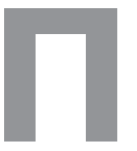

роизошедшие в стране за последние годы политические, экономические и институциональные изменения объективно создали условия и дали импульс к возрождению, становлению и развитию интегрированных объединений в сельском хозяйстве. На сегодня интегрированные формирования занимают значимое место в производстве и реализации сельскохозяйственной продукции РФ. Вместе с тем в настоящее время существует ряд проблем, сдерживающих эффективное и устойчивое развитие исследуемых структур на селе, среди которых следует особо выделить проблему выбора оптимальной системы налогообложения. Так, опыт показывает, что в настоящее время сложившаяся система налогообложения не обеспечивает выполнение всех возложенных на нее функций, а в свете проводимой государственной политики поддержки отечественного товаропроизводителя и налоговых реформ нуждается в глубоком исследовании и корректировке.

Следует отметить, что научно обоснованная система налогообложения сельскохозяйственных товаропроизводителей - одно из необходимых условий успешного реформирования аграрного сектора экономики России и повышения эффективности функционирования аграрных формирований. Вместе с тем существующая налоговая система недостаточно учитывает как 


\section{Налоги и налогообложение - №4(106) • 2013}

специфику сельского хозяйства в целом, так и особенности функционирования современных интегрированных структур в частности.

На наш взгляд, система налогообложения сельскохозяйственных предприятий в России, в том числе и интегрированных, имеет свои особенности. На основе проведенных аналитических исследований мы выделяем следующие.

1. Возможность использования сельскохозяйственными товаропроизводителями (как организациями, так и индивидуальными предпринимателями) нескольких режимов налогообложения: общего режима налогообложения, специального налогового режима в виде единого сельскохозяйственного налога (ЕСХН), упрощенной системы налогообложения, причем сторонники сельскохозяйственного налога преследуют решение двух основных проблем: снижение налогового бремени и упрощение процедуры взимания налога. Существенным фактором, влияющим на налогообложение в сельском хозяйстве является сезонность и соответственно нерегулярность поступления доходов. В Российских условиях, как и во многих других странах с переходной экономикой, последний фактор имеет особое значение;

По нашему мнению, на современном этапе развития можно выделить ряд положительных и отрицательных моментов применения специального режима налогообложения (ЕСХH).

К недостаткам ЕСХН в целом можно отнести следующие. Большиельготы по налогообложению сельского хозяйства привели к тому, что основными платежами сельхозпредприятий государству является НДС и платежи в социальные фонды. По своей природе НДС не может быть включен в ЕСХН. Что касается социальных платежей, то конструкция платежей в фонд социального страхования также не позволяет включить их в единый налог. Таким образом, полной консолидации всех налогов и платежей все равно не достигается.

Еще один недостаток ЕСХН заключается в невозможности регулировать отдельные процессы в производственной сфере с помощью данного нало- га. ЕСХН теряет гибкость, присущую разветвленной системе налогообложения, и усложняет учет.

Наряду с недостатками необходимо выделить и положительные факторы данного режима: уменьшается количество начисляемых и уплачиваемых налогов; сокращается сумма уплачиваемых налогов для слабых и средних хозяйств; оптимизируются сроки уплаты налога (учитывая то, что первое полугодие является затратным, ЕСХН будет уплачиваться раз в год); создается принцип добровольности выбора налогового режима.

Следует отметить, что влияние данной трансформации показывает величина налоговых поступлений в бюджетную систему России от аграрного сектора экономики.

Для более детального анализа поступлений от специальных режимов следует обратиться к таблице 1, где видно, что больше половины платежей приходится в основном на упрощенную систему налогообложения, так в 2011 году поступления от УСН составили 67,9 \% дохода от специальных налоговых режимов.

Единый сельскохозяйственный налог в итоговой сумме от поступлений по специальным режимам составляет всего лишь $1 \%$. Этот факт можно объяснить тем, что данный режим реализует функцию поддержания отрасли сельского хозяйства. Несмотря на незначительные поступления, наблюдается тенденция к увеличению собираемости средств от данного вида режимов, так в 2011 году доход от ЕСХН составил 3,88 млрд. руб., что более чем в 5 раз превысило поступления 2005 года. Следует отметить, что такой рост произошел за счет увеличения числа плательщиков ЕСХН, так, например, по Воронежской области в 2011 году их число составило 2084 (ед./чел.), что на 691 плательщика больше по сравнению с 2005 годом. Хотя в 2009 году произошло их незначительное снижение на 6 (ед./чел.) до 1811 (ед./чел.). Впрочем аналогичная ситуация наблюдалась и по остальным налогам, что связано с масштабностью влияния кризисных явлений на экономику России. 
Специальные налоговые режимы

\begin{tabular}{|c|c|c|c|c|c|c|c|c|}
\hline 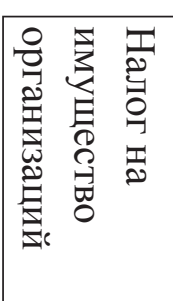 & 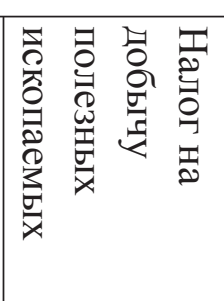 & 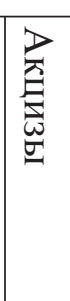 & 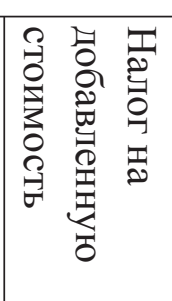 & 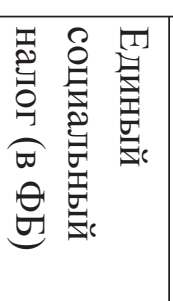 & 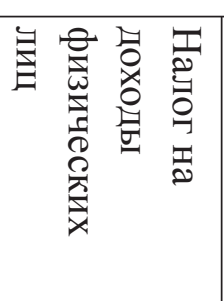 & 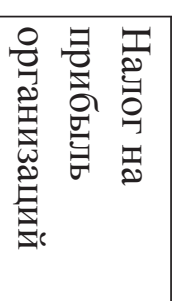 & 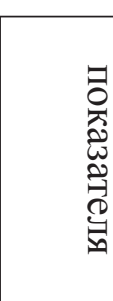 & 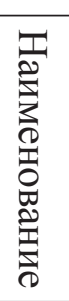 \\
\hline$\vec{N}$ & \begin{tabular}{l}
0 \\
$\infty$ \\
$\infty$ \\
\hdashline
\end{tabular} & $\stackrel{\sim}{\omega}$ & $\begin{array}{l}\vec{N} \\
\stackrel{N}{N} \\
\text { W }\end{array}$ & مَّ & $\begin{array}{l}\text { Dे } \\
\text { o }\end{array}$ & $\begin{array}{l}\vec{w} \\
\underset{N}{N} \\
\sigma\end{array}$ & 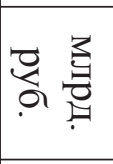 & \multirow{2}{*}{$\begin{array}{l}\text { No } \\
\text { ơ }\end{array}$} \\
\hline $\begin{array}{l}N \\
\infty \\
\infty \\
\infty\end{array}$ & $\sqrt{5}$ & $\stackrel{\rightarrow}{\infty}$ & $\begin{array}{l}N \\
N \\
\infty \\
w \\
1\end{array}$ & $\ddot{n}$ & $\underset{\omega}{\omega}$ & $\stackrel{N}{\sim}$ & $\partial^{\circ}$ & \\
\hline 总 & 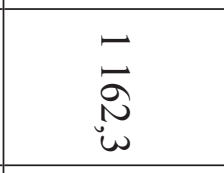 & $\begin{array}{l}N \\
0 \\
0 \\
a\end{array}$ & $\begin{array}{l}\vec{u} \\
\ddot{\Xi} \\
\vdots\end{array}$ & $\begin{array}{l}\omega \\
\tilde{\sigma}\end{array}$ & $\begin{array}{l}\mathscr{O}_{0} \\
\stackrel{\infty}{\infty}\end{array}$ & $\begin{array}{l}-\vec{a} \\
\vdots \\
\vdots \\
a\end{array}$ & 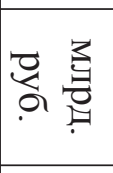 & \multirow{2}{*}{ ஜ̊ } \\
\hline$\stackrel{\sim}{\sim}$ & $\begin{array}{l}\infty \\
\pm \\
\pm\end{array}$ & $\stackrel{\vec{\omega}}{\vec{\omega}}$ & $\begin{array}{l}n \\
+ \\
0 \\
0\end{array}$ & $\ddot{i}$ & $\stackrel{\vec{t}}{\overrightarrow{0}}$ & $\begin{array}{l}n \\
\tilde{u} \\
u\end{array}$ & $\partial^{\circ}$ & \\
\hline 古 & 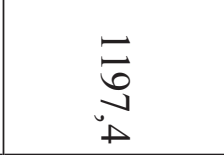 & $\begin{array}{l}0 \\
\infty \\
0 \\
0 \\
0\end{array}$ & 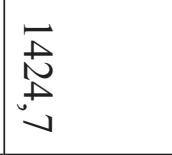 & $\begin{array}{l}\text { b } \\
\text { cur } \\
\text { o }\end{array}$ & $\begin{array}{l}\bar{N} \\
\stackrel{\alpha}{-}\end{array}$ & $\underset{N}{N}$ & 可 & \multirow{2}{*}{ 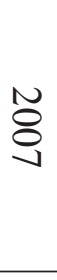 } \\
\hline$\ddot{w}$ & $\vec{\sim}$ & $\begin{array}{l}\omega \\
b \\
\phi\end{array}$ & wo & $\ddot{u}$ & $\underset{N}{\sim}$ & $\begin{array}{l}\text { No } \\
\text { 心' } \\
\omega\end{array}$ & $a^{\circ}$ & \\
\hline $\begin{array}{l}w \\
w \\
w \\
\omega\end{array}$ & $\begin{array}{l}\vec{\partial} \\
\infty \\
\infty \\
0\end{array}$ & $\stackrel{\omega}{\omega}$ & $\begin{array}{l}\vec{D} \\
\infty \\
\infty \\
\vdots \\
\forall\end{array}$ & $\begin{array}{l}\mathscr{2} \\
\stackrel{\infty}{\infty}\end{array}$ & $\begin{array}{l}\vec{a} \\
\text { ù } \\
\infty\end{array}$ & $\begin{array}{l}\tilde{N} \\
u \\
w \\
0\end{array}$ & 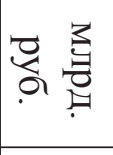 & \multirow{2}{*}{ 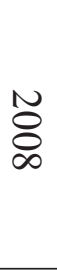 } \\
\hline $\begin{array}{l}\omega \\
\infty \\
\omega \\
\omega\end{array}$ & $\stackrel{N}{\stackrel{N}{N}}$ & $\stackrel{\sim}{\sim}$ & $\begin{array}{l}N \\
N \\
\text { O }\end{array}$ & $a$ & $\stackrel{\Xi}{\Xi}$ & $\begin{array}{l}\stackrel{N}{0} \\
\stackrel{\sim}{A} \\
\end{array}$ & $0^{\circ}$ & \\
\hline $\begin{array}{l}w \\
\infty \\
w \\
\infty \\
\infty\end{array}$ & $\underset{\substack{\breve{u} \\
. \infty}}{\vec{D}}$ & $\begin{array}{l}w \\
\text { N } \\
\text { in }\end{array}$ & N & 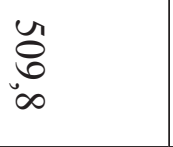 & $\begin{array}{l}\vec{a} \\
\text { जो } \\
0\end{array}$ & $\begin{array}{l}\hat{N} \\
\stackrel{+}{+} \\
\sigma\end{array}$ & 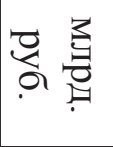 & \multirow{2}{*}{ 论 } \\
\hline$\ddot{2}$ & $\begin{array}{l}\vec{u} \\
\ddot{u} \\
\ddot{n}\end{array}$ & $\begin{array}{l}\vec{D} \\
\infty \\
\infty\end{array}$ & $\underset{y}{\beth}$ & $\vec{u}$ & $\begin{array}{l}\stackrel{N}{ \pm} \\
\stackrel{ \pm}{u}\end{array}$ & $\begin{array}{l}\infty \\
\infty \\
0\end{array}$ & $a^{\circ}$ & \\
\hline $\begin{array}{l}\mathbb{N} \\
\infty \\
\infty \\
\text { Un }\end{array}$ & $\begin{array}{l}\vec{A} \\
\stackrel{0}{0} \\
\text { a }\end{array}$ & 点 & 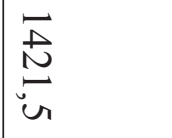 & $\begin{array}{l}\vec{b} \\
\infty \\
\infty \\
a\end{array}$ & $\begin{array}{l}= \\
\infty \\
0 \\
a\end{array}$ & $\begin{array}{l}\infty \\
\stackrel{\infty}{J} \\
\stackrel{u}{u}\end{array}$ & 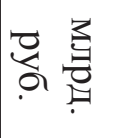 & \multirow{2}{*}{$\begin{array}{l}\text { O } \\
0\end{array}$} \\
\hline $\begin{array}{l}u r \\
\text { ur } \\
\text { ur }\end{array}$ & $\vec{\alpha}$ & un & $\begin{array}{l}\vec{y} \\
0 \\
0\end{array}$ & $\begin{array}{l}u \\
\infty \\
\infty \\
\infty\end{array}$ & $\stackrel{N}{\sim}$ & $\begin{array}{l}\text { N } \\
\tilde{N} \\
\text { Un }\end{array}$ & $\partial^{\circ}$ & \\
\hline 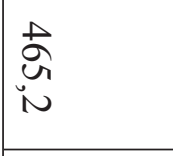 & $\begin{array}{l}\text { N } \\
\stackrel{1}{ \pm} \\
\text { un } \\
\text { un }\end{array}$ & oे & $\begin{array}{l}\infty \\
+ \\
+\infty \\
6\end{array}$ & $\begin{array}{l}+ \\
\infty \\
\text { un }\end{array}$ & $\begin{array}{l}\overrightarrow{8} \\
+5 \\
0\end{array}$ & $\begin{array}{l}\stackrel{N}{N} \\
\text { O } \\
\text { W }\end{array}$ & 氜 & \multirow[t]{2}{*}{$\stackrel{N}{\circ}$} \\
\hline$\stackrel{+}{8}$ & $\begin{array}{l}\text { No } \\
\stackrel{N}{N}\end{array}$ & 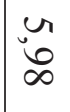 & $\begin{array}{l}\infty \\
\infty \\
\alpha\end{array}$ & $\stackrel{+}{\infty}$ & $\begin{array}{l}\vec{\sigma} \\
\stackrel{\sim}{\perp}\end{array}$ & $\begin{array}{l}\stackrel{N}{N} \\
\stackrel{N}{*}\end{array}$ & $\partial^{\circ}$ & \\
\hline
\end{tabular}

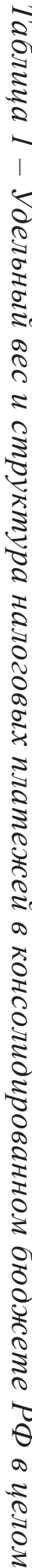




\begin{tabular}{|c|c|c|c|c|}
\hline $\mathbb{J}_{0}$ & & ָ̃. & $\stackrel{0}{\underset{ }{\approx}}$ & $x$ \\
\hline $\begin{array}{l}0 \\
\mathbb{f}^{\prime}\end{array}$ & & $\begin{array}{l}\overrightarrow{\tilde{D}} \\
\vec{v}\end{array}$ & $\begin{array}{l}n \\
\equiv\end{array}$ & $\begin{array}{l}\infty \\
0 \\
0 \\
0\end{array}$ \\
\hline$\stackrel{\stackrel{\sim}{\sim}}{\sim}$ & & $\begin{array}{l}\tilde{n}_{2} \\
\text { s }\end{array}$ & $\stackrel{\sim}{\sim}$ & $x$ \\
\hline$\underset{\infty}{\infty}$ & & $\hat{\tilde{\hat{N}}}$ & 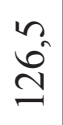 & $\begin{array}{l}\overrightarrow{0} \\
\stackrel{\sim}{\infty}\end{array}$ \\
\hline$\stackrel{\nabla_{-}}{-}$ & & $\begin{array}{l}\mathscr{s} \\
\infty \\
\sim\end{array}$ & $\begin{array}{l}0 \\
\text { ñ. }\end{array}$ & $x$ \\
\hline ñ & & 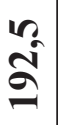 & $\hat{\text { å }}$ & $\frac{\pi}{\sigma}$ \\
\hline $\begin{array}{l}n \\
\hat{o}\end{array}$ & & $\begin{array}{l}\stackrel{\sim}{y} \\
\sim \\
\sim\end{array}$ & $\underset{=}{ \pm}$ & $x$ \\
\hline 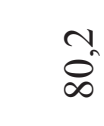 & & 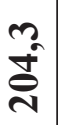 & $\begin{array}{l}0 \\
\text { on }\end{array}$ & $\begin{array}{l}0 \\
\frac{n}{5} \\
\frac{1}{0}\end{array}$ \\
\hline$\stackrel{\Delta}{\sigma}$ & & $\frac{\widetilde{z}}{\mathfrak{v}}$ & $\stackrel{\vec{n}}{-}$ & $\rtimes$ \\
\hline$\hat{\sigma}$ & & 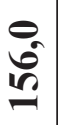 & $\stackrel{O}{\cong}$ & $\begin{array}{l}a \\
\tilde{n} \\
\approx\end{array}$ \\
\hline$\frac{N}{0}$ & & $\stackrel{2}{=}$ & $\stackrel{\Xi}{\Xi}$ & $x$ \\
\hline $\begin{array}{l}\nabla_{n} \\
\stackrel{\nabla}{*}\end{array}$ & & $\begin{array}{l}b \\
\mathfrak{J} \\
\Xi\end{array}$ & $\frac{a}{\nabla}$ & సิ \\
\hline مू & & $\underset{\sim}{\stackrel{\sigma}{+}}$ & $\stackrel{\overbrace{}}{-}$ & $\rtimes$ \\
\hline $\begin{array}{l}n \\
+\infty\end{array}$ & & 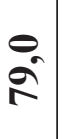 & $\overrightarrow{6}$ & $\begin{array}{l}\text { N } \\
\infty \\
\text { n } \\
n\end{array}$ \\
\hline 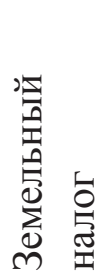 & 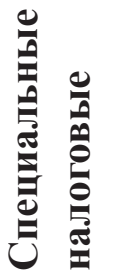 & |àd & 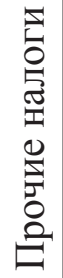 & 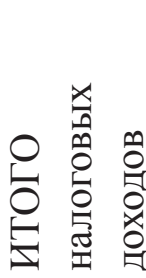 \\
\hline
\end{tabular}

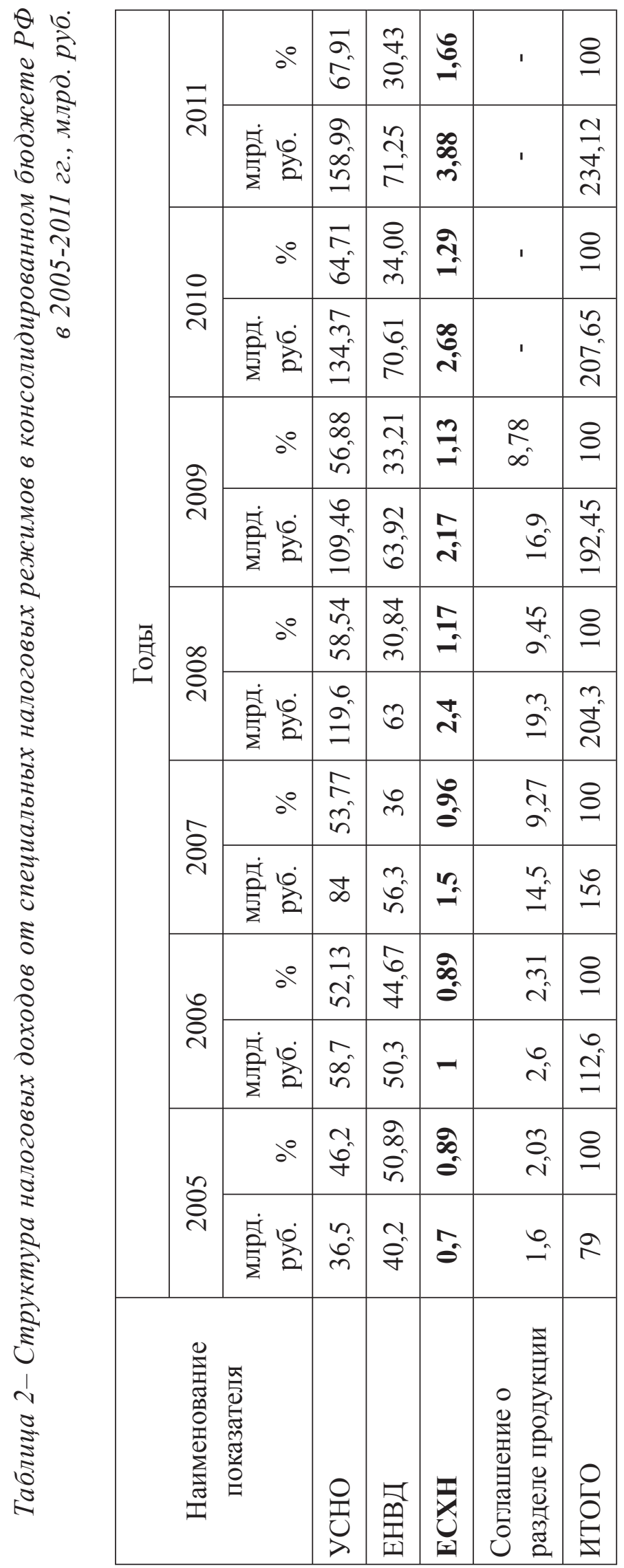


Специальные налоговые режимы

Проведенный сравнительный анализ показал, что предельная величина налогового бремени в аграрном секторе экономики зависит не только от величины совокупного обложения, но и от эффективности производства и финансового состояния предприятия. Следовательно, предельный размер налоговой нагрузки должен определяться с учетом отраслевой принадлежности хозяйствующих субъектов и связанной с этим спецификой производственной деятельности.
Таким образом, нам представляется целесообразным выделить ряд особенностей, интегрированный сельхозпредприятий, которые непосредственно оказывают влияние на выбор той или иной системы налогообложения. Их можно разделить на объективные и субъективные. Вместе с тем, такое деление носит условный характер.

К объективным, не зависящим от решений экономического субъекта особенностям, на наш взгляд, можно отнести прямую зависимость результатов сель-

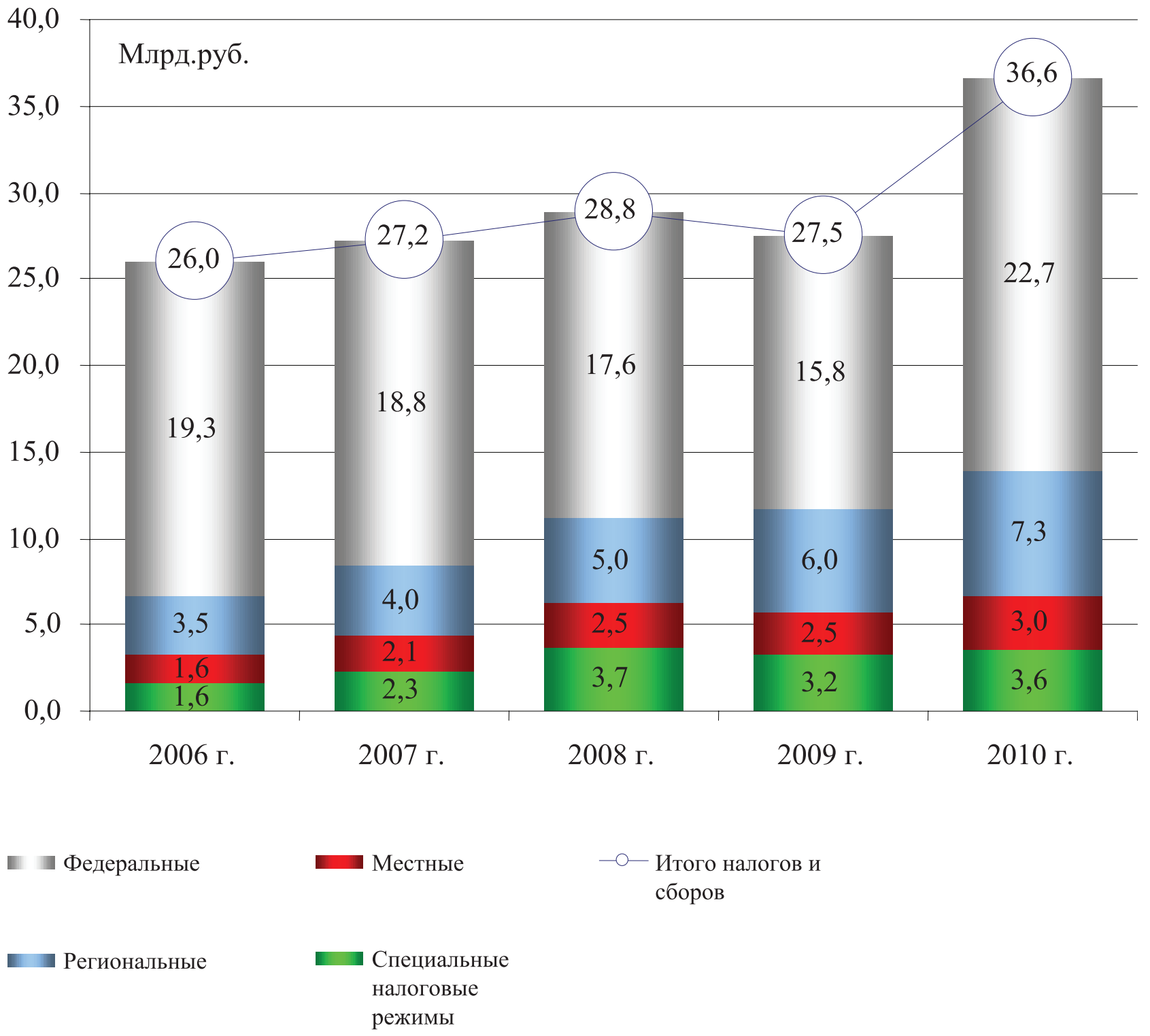

Рисунок 1 - Структура налоговых платежей в сельском хозяйстве РФ, млрд. руб. 


\section{Налоги и налогообложение - №4(106) • 2013}

скохозяйственного производства от природно-климатических условий, сезонность основных отраслей производства.

К субъективным особенностям относятся структура, состав и доходность отраслей производства, обеспеченность рабочей силой (особенно при использовании сезонных работников), уровень изношенности средств производства (и, как следствие, наличие или отсутствие потребности в обновлении сельхозтехники), месторасположение сельскохозяйственного предприятия, размеры и структура сельскохозяйственных угодий и др.

Особое внимание, на наш взгляд, следует обратить на такие отраслевые особенности как доля отрасли в доходе от реализации продукции, финансовые результаты деятельности и ресурсоемкость производства.

Так, например, сочетание основных и дополнительных отраслей является законодательным ограничителем при выборе общего или специального режима налогообложения. При этом финансовые результаты выбранных отраслей оказывают влияние на размер налога на прибыль. Отраслевые характеристики движения денежных потоков формируют налоговую платежеспособность хозяйствующего субъекта, что очень важно при резко выраженной сезонности сельскохозяйственного производства. От уровня фондо- и трудоемкости производства при сложившемся сочетании отраслей зависит, соответственно, размер налога на имущество организаций, налога на доходы физических лиц и единого социального налога. Месторасположение сельскохозяйственного предприятия также является стратегическим фактором налоговой оптимизации. Оно непосредственно формирует величину земельного налога и опосредованно оказывает влияние на налогообложение финансовых результатов.
Наряду с этим, хотелось бы отметить, что сравнительный анализ двух режимов налогообложения, проведенный на предприятиях, позволил сделать вывод, что налоговая нагрузка предприятий, уплачивающих ЕСХН, снижается примерно в два раза по сравнению с предприятиями, применяющими общий режим налогообложения.

2. Специфику налогообложения в сельском хозяйстве определяют следующие факторы: почвенно-климатический и выгодность географического расположения земель (различие в кадастровой стоимости земель сельскохозяйственного назначения), существующие отличия в ставках НДС на производимые товары и приобретаемые ресурсы и др.

Мы считаем, что в системе налогообложения сельского хозяйства должна учитываться необходимость обеспечения продовольственной безопасности страны на основе создания условий для развития отечественного сельскохозяйственного производства. Таким образом, при построении налоговой системы должны учитываться такие особенности сельскохозяйственной отрасли как сезонный характер производства, зависимость его хозяйственных результатов от погодных факторов, территориальная разбросанность производства по различным природноклиматическим зонам и дифференциация почвенного плодородия, значительный удельный вес рентной составляющей в результатах хозяйствования. Кроме того, должно учитываться финансово-экономическое состояние сельскохозяйственных товаропроизводителей и диспаритет цен на сельскохозяйственную продукцию и потребляемые в отрасли ресурсы промышленного производства.

3. Налогообложение аграрных формирований заключается в необходимости госу- 
дарственного регулирования на основе предоставления льгот по различным налогам (по налогу на прибыль, земельному налогу, налогу на имущество организаций и т.д.), экспортно-импортной деятельности через квотирование и установление таможенных пошлин на ввозимые продовольственные товары и т.д.

Следует отметить, что налоговое регулирование является весьма мощным инструментом государственного регулирования экономики любой страны. Специфика налогового регулирования заключается в том, что для предприятий аграрной сферы в современных условиях первичной является регулирующая функция налогов, а не фискальная. Связано это с тем, что ввиду объективных причин более половины современных аграрных формирований находится в весьма тяжелых финансовых условиях: уровень заработной платы почти в три раза ниже, чем в среднем по экономике страны; низкий уровень и большая изношенность материально-технической базы, и поэтому отчисление от прибыли, доходов физических лиц, налога на имущества весьма незначительны.

Таким образом, мы считаем, что на современном этапе развития основной функцией налогов в аграрной сфере является регулирующая, при этом налоговое регулирование должно быть направлено, прежде всего, на регулирование экспортноимпортной деятельности.

Средний уровень налогового бремени в зарубежных странах колеблется от 15 до $40 \%$. Так, величина налогового бремени в России заметно ниже уровня стран ЕC и Канады, примерно на одном уровне с Японией и США и много выше, чем в бурноразвивающихся экономиках (Индия и Китай), что является отрицательным фактом, учитывая необходимость увеличения темпов экономического развития РФ до уровня Индии и Китая.

Налоговое бремя в сельском хозяйстве РФ существенно ниже, чем в среднем по экономике (около 4,6\%), что объясняется существенными льготами для предприятий агарной сферы, а именно: льготная ставка НДС, применение специального налогового режима в виде ЕСХН, нулевая ставка по налогу на прибыль и т.д. (рис. 2 - стр. 252).

Очевидно, что низкая налоговая нагрузка в целом положительно сказывается на функционировании предприятий аграрной сферы и должно способствовать привлечению инвестиций в данный сектор экономики страны. Но вместе с тем в существующей налоговой системе РФ имеются определенные противоречия, которые тормозят этот процесс. Речь идет о применении специального режима налогообложения для сельхозтоваропоризводителей. Дело в том, что одна из основных задач данного налогового режима - это повышение инвестиционной привлекательности сельского хозяйства.

Между тем практика применения ЕСХН показывает, что организациям или индивидуальным предпринимателям, собирающимся привлекать инвестиционные ресурсы в развитие предприятия, экономически выгоднее оставаться на общем режиме налогообложения.

Таким образом, существующая редакция главы 26.1 НК РФ делает экономически не оправданным применение специального налогового режима для сельскохозяйственных товаропроизводителей в случае привлечения крупных инвестиционных ресурсов на развитие предприятия. В этой связи на современном этапе развития сельского хозяйства, когда отрасль остро нуждается в инвестициях, видится целесообразным исключение НДС из перечня неуплачиваемых налогов для сельскохозяйственных товаро- 


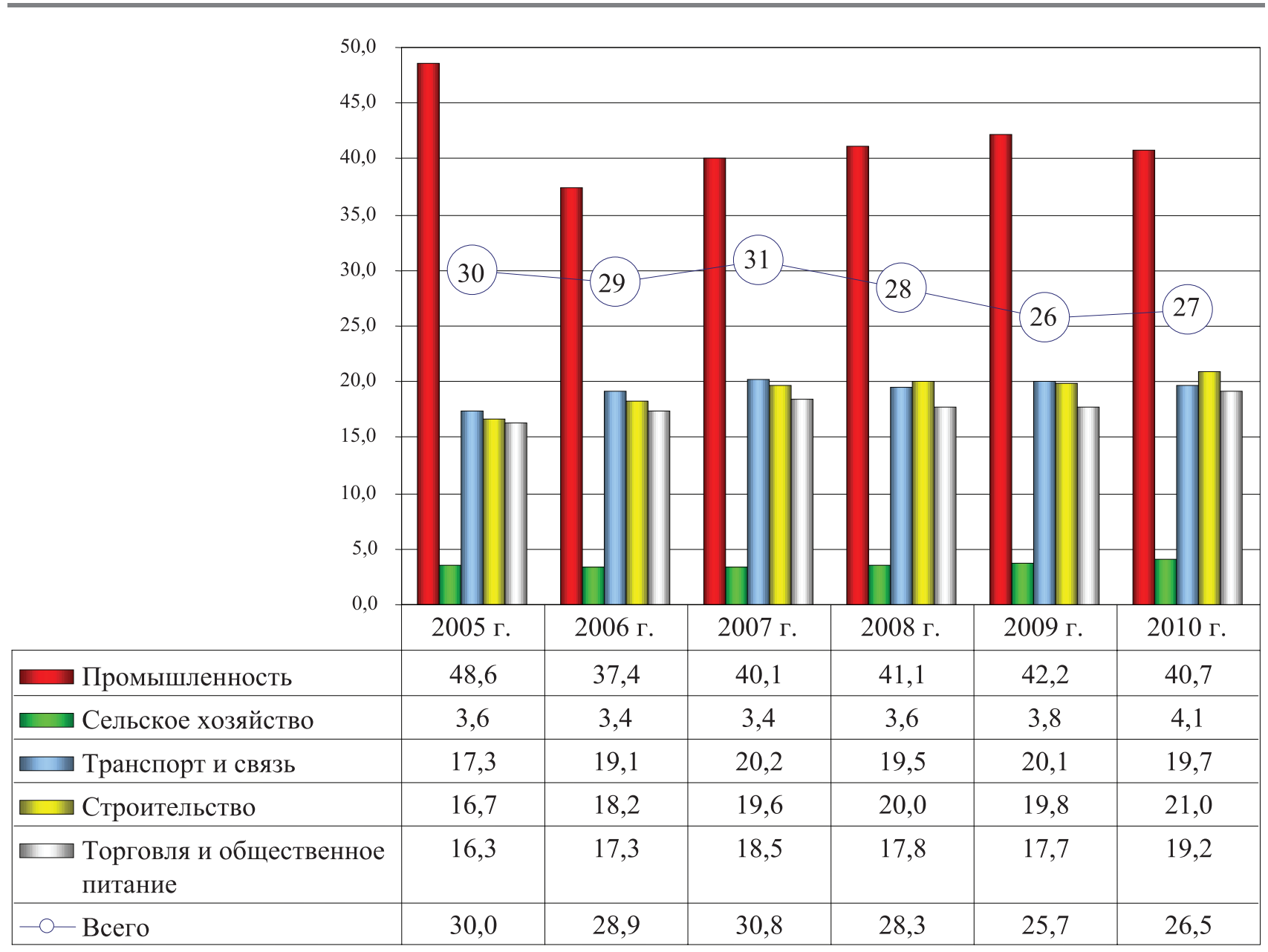

Рисунок 2 - Налоговая нагрузка на основные отрасли экономики РФ, \%

производителей, применяющих специальный режим налогообложения в виде ЕСХН.

Внешнеэкономическое регулирование через таможенные пошлины и тариф также является составной частью налогового регулирования и имеет свои особенности в аграрном секторе экономики.

Актуальность приобретают вопросы совершенствования системы государственного регулирования сельского хозяйства, включающей различные формы и методы госрегулирования, учитывающие современное состояние и специфику аграрной сферы, способствующие повышению конкурентоспособности и устойчивости функционирования современных аграрных формирований и достижению социальной стабильности в отрасли.

Так, постановлением Правительства РФ 14 июля 2012 года была принята Государственная программа развития сельского хозяйства и регулирования рынков сельскохозяйственной продукции, сырья и продовольствия на 2013 - 2020 годы.

Следует отметить, что одной из основных целей данной Государственной программы является повышение конкурентоспособности российской сельскохозяйственной продукции на внутреннем и внешнем рынках.

Представляется, что с вступлением в ВТО перед нашей страной открываются, 
с одной стороны, новые возможности, с другой, возникают новые проблемы, определяемые рядом факторов, среди которых наиболее значимыми являются:

- в сфере производства - уровень валовой сельскохозяйственной продукции ниже дореформенного;

- в сфере экономики - низкая доходность у большей части сельхозтоваропроизводителей и высокая ссудная задолженность;

- в инновационной сфере - дефицит собственных и привлеченных инвестиционных ресурсов; в социальной сфере
- низкая оплата труда занятых в отрасли, медленное развитие социальной инфраструктуры сельских территорий, демографические проблемы ${ }^{1}$.

Так же отрицательные последствия ожидаются от изменения таможенно-тарифного регулирования. В целом по тарифу на сельскохозяйственную продукцию и продовольствие средневзвешенная ставка будет снижена на треть от ее текущего уровня (с $15,6 \%$ до 11,3\% на конец переходного периода), а по отдельным позициям произойдет более сильное снижение.

Таблица 1 - Изменение размера таможенного тарифа на продовольственные товары, вводимые Протоколом по присоединению России к ВТО

\begin{tabular}{|c|l|c|c||}
\hline $\begin{array}{c}\text { Код } \\
\text { товара }\end{array}$ & \multicolumn{1}{|c|}{ Наименование товара } & $\begin{array}{c}\text { Уровень тарифа по } \\
\text { ВТО, } \%\end{array}$ & $\begin{array}{c}\text { Уровень тарифа по } \\
\text { ЕТТ, } \%\end{array}$ \\
\hline 0103 & Свиньи живые & 5 & 40 \\
\hline 0203 & $\begin{array}{l}\text { Свинина свежая, охлажденная или } \\
\text { замороженная: }\end{array}$ & 65 & 75 \\
\hline \hline 0206 & Свинина сверх квоты & 0 & 15 \\
\hline 0208 & $\begin{array}{l}\text { Прочие мясо и пищевые мясные } \\
\text { субпродукты }\end{array}$ & 15 & 25 \\
\hline 0402 & Молоко и сливки сгущенные & 15 & 25 \\
\hline 0404 & Молочная сыворотка & 15 & 25 \\
\hline 0406 & Сыры и творог & 15 & 38 \\
\hline 0902 & $\begin{array}{l}\text { Чай со вкусо-ароматическими } \\
\text { добавками }\end{array}$ & 9,5 & 19 \\
\hline \hline 1006 & Рис & 12,5 & 20 \\
\hline 1511 & Масло пальмовое & 10 & 29 \\
\hline 1601 & Колбасы & 3 & 0,4 \\
\hline \hline
\end{tabular}

${ }^{1}$ Ушачев, И. Г. Меры по обеспечению конкурентоспособности сельского хозяйства в условиях присоединения России к ВТО / И. Г. Ушачев // АПК: экономика, управление. - 2012. - №9. - С. 9-14. 


\section{Налоги и налогообложение - №4(106) • 2013}

Для минимизации рисков в агропромышленном комплексе, возникающих в связи с присоединением России к ВТО, ученые считают целесообразным:

1. пересчитать запланированный объем поддержки сельхозтоваропроизводителей до уровня, согласованного Протоколом о присоединении России к ВТО;

2. одновременно с Государственной программой развития сельского хозяйства и регулирования рынков сельскохозяйственной продукции, сырья и продовольствия на 2013-2020 годы принять федеральные целевые программы:

- «Устойчивое развитие сельских территорий на 2014-2017 годы и на период до 2020 года» и обеспечить ее финансирование в необходимых объемах;

- «Развитие мелиорации сельскохозяйственных земель России на период до 2020 года»;

- «Развитие отечественного сельскохозяйственного машиностроения для сельского хозяйства, пищевой и перерабатывающей промышленности» на основе подготовленной Минпромторгом России Стратегии развития сельскохозяйственного машиностроения;

3. рассмотреть возможность внесения изменений в обязательства России в ВТО по корректировке ставок таможенно-тарифного регулирования на чувствительные товарные позиции, включая импорт живых свиней, пищевых субпродуктов, колбас, молочной продукции, риса и пальмового масла;

4. принять систему мер для обеспечения доходности сельскохозяйственного производства с целью повышения инвестиционной привлекательности отрасли как на основе мер по повышению доли сельскохозяйственных товаропроизво- дителей в конечной цене продукции, так и увеличения государственной поддержки ${ }^{2}$.

Таким образом, нам представляется, что научно обоснованная система налогообложения сельхозтоваропроизводителей - одно из необходимых условий успешного реформирования аграрного сектора экономики России. Существующая налоговая система слабо учитывает специфику сельского хозяйства, а в большей степени интегрированных структур, которые в настоящее время являются основой сельского хозяйства. Эффективность сельского хозяйства, в отличие от других отраслей экономики, в значительной степени, как уже говорилось, определяется складывающимися природными и климатическими условиями. Они оказывают влияние не только на урожайность сельскохозяйственных культур, но и предопределяют уровень затрат хозяйствующего субъекта на осуществление сельскохозяйственной деятельности. Многие исследователи поднимали вопрос о необходимости введения дифференцированного подхода к налогообложению сельского хозяйства в зависимости от складывающихся природно-климатических условий, что позволит обеспечить равные условия хозяйствования. Однако до настоящего времени механизмы дифференциации условий налогообложения не разработаны. Помимо этого многоканальная система налогов ставит сельхозпредприятия в неравные условия по отношению к налогоплательщикам других отраслей хозяйственного комплекса страны. Пробелы в налоговом

\footnotetext{
${ }^{2} \mathrm{O}$ рисках и угрозах обеспечения конкурентоспособности продукции сельского хозяйства в условиях присоединения России к ВТО // ГНУ ВНИИЭСХ совместно с экономическими институтами Россельхозакадемии [сайт]. URL: http:www.vniiesh.ru/news/9651.htm
} 
законодательстве не дают возможности крупным (интегрированным) сельхозпредприятиям получения налоговых льгот, что тормозит процесс инвестирования.

\section{Библиография:}

1. Карзаева Н.Н., Медведева Е. / Выбор системы налогообложения сельскохозяйственными предприятиями как фактор финансовой устойчивости // Бухучет в сельском хозяйстве. - 2009. - №9.

2. Налоговый кодекс Российской Федерации часть первая от 31 июля 1998 г. № 146Ф3 и часть вторая от 5 августа 2000 г. № 117-Ф3 (с изм. и доп. от 09.09.2012г.)// Справочно-правовая система «Гарант»: [Электр.ресурс]/НПП «Гарант-Сервис». - Послед. обновление 10.10.2012.

3. О рисках и угрозах обеспечения конкурентоспособности продукции сельского хозяйства в условиях присоединения России к ВТО // ГНУ ВНИИЭСХ совместно с экономическими институтами Россельхозакадемии [сайт]. URL: http:www.vniiesh.ru /news/9651.htm

4. Оптимизация параметров развития производства и налогообложения в интегрированных формированиях АПК: моно- графия / А.К. Камалян, А.С. Оробинский, И.В. Оробинская, Ю.Н. Парахин; под редакцией проф. Камаляна А.К. - Воронеж: ФГОУ ВПО ВГАУ, 2010. - 203 с.

5. Ушачев, И. Г. Меры по обеспечению конкурентоспособности сельского хозяйства в условиях присоединения России к ВТО / И. Г. Ушачев // АПК: экономика, управление. - 2012. - №9. - С. 9-14.

6. Федеральный закон Российской Федерации от 25 июня 2012 г. № 94-Ф3 «О внесении изменений в части первую и вторую Налогового кодекса Российской Федерации и отдельные законодательные акты Российской Федерации» // Собрание законодательства РФ - 25.06.2012. - № 26, С.- 3447

\section{References (transliteration):}

1. Karzaeva N.N., MedvedevaE./Vybor sistemy nalogooblozhenija sel'skohozjajstvennymi predprijatijami kak faktor finansovoj ustojchivosti // Buhuchet v sel'skom hozjajstve. - 2009. - №9.

2. Ushachev, I. G. Mery po obespecheniju konkurentosposobnosti sel'skogo hozjajstva v uslovijah prisoedinenija Rossii k VTO / I. G. Ushachev // APK: jekonomika, upravlenie. - 2012. - №9. - S. 9-14. 